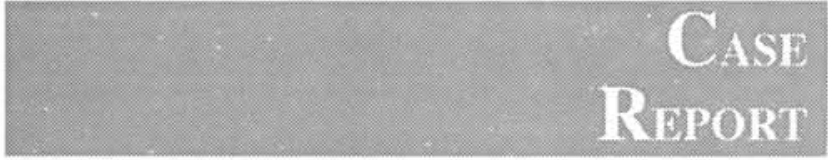

Israel Szajnbok, Fernando Lorenzi, Aldo Junqueira

Rodrigues Jr., Luis Fernando Correa Zantut, Renato Sérgio Poggetti, Elian Steinman, Dario Birolini

\title{
Gallstone ileus resulting in strong intestinal obstruction
}

\author{
Trauma Surgery Discipline, First Aid Unity, Hospital das Clínicas, \\ Faculdade de Medicina, Universidade de São Paulo - São Paulo, Brazil
}

\begin{abstract}
Mechanic intestinal obstruction, caused by the passage of biliary calculus from vesicle to intestine, through fistulization, although not frequent, deserve study due to the morbi-mortality rates.

Incidence in elder people explains the association with chronic degenerative diseases, increasing complexity in terms of therapy decision.

Literature discusses the need and opportunity for the one or two-phase surgical attack of the cholecyst-enteric fistule, in front of the resolution on the obstructive urgency and makes reference to Gallstone lleus as an exception for strong intestinal obstruction. The more frequent intestinal obstruction observed is when it occurs a Gallstone lleus impacting in terms of ileocecal valve. The authors submit a Gallstone lleus manifestation as causing strong intestinal obstruction, discussing aspects regarding diagnostic and treatment.
\end{abstract}

UNITERMS: Intestinal obstruction. Gallstone ileus. Colycist-enteric (biliodigestive) fistule.

\section{INTRODUCTION}

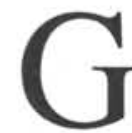
allstone Ileus is a mechanical obstructive situation caused by the impacting of the calculus on the intestine, originated from the biliar vesicle through the cholecyst-enteric fistule.

It was observed during the last years, in the most developed countries, that the life-time increased and, consequently, the incidence of Gallstone Ileus. This

\section{Address for correspondence:}

Luis Fernando Correa Zantut

Av. Brigadeiro Luis Antonio, 452

São Paulo - SP - Brasil - CEP 01401-002 incidence is statistically significative in people over 70 years age, predominating in women. It represents a $1 \%$ $4 \%$ of the strong abdominal obstructions $(4,10,14)$.

Patients of the above mentioned group age present a $80 \%-90 \%$ of disease association, reaching one or more organic systems, being predominant the cardiovascular and diabetes mellitus diseases $(4,6,7,10,19)$.

Mortality ranges from $12 \%-27 \%$, being mortality related to the seriousness of the clinical behavior and, mostly, to the associated diseases $(4,6,8)$.

Most of the calcules cause intestine obstruction when impacting at the ileus-termini $(8,10,19)$.

Treatment continues controverse, discussions being held on the need and the opportunity of undertaking cholecyst-enteric fistule during the initial surgery $(1,4,6,17)$.

We found as being opportune the publishing of the Gallstone-Ileus case, with high intestine obstruction, diagnosticated in the pre-operative through computerized tomography and to discuss adequacy of the treatment established. 


\section{DESCRIPTION OF THE CASE}

Patient 80 years old, presenting slightly cardiac insufficiency and two previous cerebral-vascular accidents with minimum consequences, was attended at another service unity, presenting a 4-days emesis, containing alimentary rests, without preceding cholecystopatic symptoms.

Digestive endoscopy presented gastroduodenal alimentary-estasis, acute gastroduodenitis; patient continued under observation.

On the subsequent days, besides the single radiography, computerized abdominal ultrasonography and tomography were performed. Exames showed aerobily presenting no calcules in the biliar vesicle, duodenal tissues increase and suggestive radiopaque immage of the calculus according to the Treitz angle level (Fig.1).

In sequence, patient began to present pain and abdominal distension, worse emesis levels, ceasing of gas/ intestive functions, being then transfered to our unity.

Admitted 7 days after the beginning of the symptoms, unicteric and feverless, indicating acute abdominal obstructive situation.

After pre-operative care, was submitted to a medium laparotomy being found cholecyst-duodenal fistule with intensive fibrose, irregular $3,5 \mathrm{~cm}$ calculus placed on the distal jejune, high distension and venous estasis. Calculus was fragmented casually during manipulation. Manual propulsion of fragments in direction to the colon, together with the estasis enteria content, was chosen after this.

As the clinical evaluation of the patient was adequate, she was submitted to a cholecystectomy and cholecystorrhaphy of the second duodenal portion, place of the fistule, with a transverse suture in two levels. Radiologic examination of the biliary duct, in the preoperative was normal and peritoneal cavity was drained. Total anesthesic period was of 6 hours and no blood transfusion appeared necessary.

Patient showed ileo adynamic complication during 5 days, without any other occurrence. Considered in conditions to leave hospital on the 13th day.

\section{DISCUSSION}

Clinical situation regarding Gallstone Ileus is changeable. Symptoms may start from 4 to 8 days before the clear obstructive manifestation, showing in this case intermitent movement of the calculus until its final impacting. This occurs, generally, jointly the ileus-cecal valve $(4,8,10,19)$.

In the present case, clinical situation initially suggested impacts of the calculus in the different segments of the small intestine. This explains not only the modification of the symptoms presented, but also the surgical point in a distant segment from the indicated in the pre-operative computerized tomography.

\section{Phisiotherapy}

Bilio-digestive fistules have many wellknown causes. One of them is the duodenal ulcer perforated to the biliar ducts, that should not be confused with the cholecystenteric fistules, consequence of repeated vesicle inflamatory occurrences.

These occurrences result in pericholecystis and adherence to the tissues of the closer organs. Tissue adherences being present, calculus impacts occurring in the interior of the vesicle, there is a risk of visceral tissue scarification and, as a consequence, also the intestinal ring probably adhered there, enabling the passage of the fistule to the intestine.

\section{Clinical situation}

About $1 / 3$ of patients do not mention any previous biliar disease and $1 / 3$ only make reference to occurrencies resembling to acute cholecystitis recently happened $(7,8,10,18)$. In spite of difficulties in collecting information resulting from the previous cerebral vascular accident, our pacient denied symptoms of a previous biliar disease.

A calcule passing through the fistule, may be elliminated through emesis, or impact in intestine (4).

The Gallstone Ileus is frequently characterized by abdominal collic pains, bilious emesis or, eventually, feculent, seldom icterus. Its difference in diagnostic includes other causes than the intestinal obstruction and mesenteric ischemia.

Diagnostic is not always immediate. There are cases where the confirmation of the diagnostic hypothesis is only possible in the inter-operative. Some authors comment on surgeries indicated 3 or 5 days after hospital entry, as result of diagnose difficulty or for establishing associated organic insufficiencies $(6,14,18,20)$. 


\section{Subsidiary exames}

The clinic evaluation is complemented by radiographies, ultrasonography, computerized tomography and digestive endoscopy.

Single abdominal radiography of the Gallstone Ileus may show-up according the Rigler's triad: mechanical obstruction, aerobily and radiopaque calculus in unusual point or progressive local changing $(2,3,10)$. Two of these 3 signals appear in at least half of the patients presenting Gallstone Ileus.

Aerobily frequently appears associated to precedent biliar-surgery or to the Oddi Sphincter insufficiency. In order to occur in the cholecyst-esteric fistule, cystic duct must be acquaintant or a biliar duct fistule must be present.

Another radiologic signal is the appearing of two hydroaereal levels in the right hypochondriac, the medial corresponding to duodene and the lateral to the biliar vesicle. The frequent gas interference on the calcule placed out of the vesicle even when being radiopaque, makes its visualization difficult.

The contrasting radiography may identify the presence of the fistule and the level of the mechanical obstruction.

In the abdominal ultrasonography cholecyst-enteric fistule may be observed,so as the residual cholelithiasis and calcules impacted in the intestine $(2,4,18)$. However, two factors must be considered: first, the residual cholelithiasis may not occur; second, that its presence may be noted, eventually, only through ultrasonography.

Abdominal computerized tomography may show-up calcules not observed through single tomography or ultrasonography. It may identify also the gas presence or contrasts in the biliar duct or vesicle, which presence is understood as a bilio-digestive fistule occurrence (2).

High digestive endoscopy enables visualization of eventual calculus impacted in the duodene. Sometimes, identification is followed by its prompt removal. When this is not possible, surgical removal is indicated (4).

\section{Diagnostic}

Syndromic diagnose was done through the interpretation of the clinic evaluation, after development of the signal and symptoms clearly obstructive. As on the single radiography the calcule image was very slight, etiological diagnostic was stated only after the computerized tomography.

Retrospectively, Rigler triad was possible to be recognized through the single radiography or our patient.

\section{Surgical treatment}

Surgical treatment is adopted for the Gallstone Ileus.

As already told, when there is a duodenal impact, endoscopic removal is possible.

There still is a small group of patients the lithotripsia by waves of shock is used for (4).

In the surveys on the Gallstone Ileus surgeries, calculus impacted in the short intestine are almost always found. According the authors, impact occurs in 50\% to $70 \%$ of the ileus terminal cases, including the ileus-cecal valve. About $20 \%$ to $40 \%$ in the proximal or jejune ileus and the remaining $10 \%$ in the duodenum $(4,13,15)$.

The main local of impactation in the colon is the sigmoid. Usually occurs in the presence of cholecystcolonic fistules and previous sigmoidean estenosis, caused by preceding diverticulitis manifestation. Calcules able to cause obstruction at this level would not pass through the ileus-cecal valves in case the fistule with vesicle would not occur with the colonic segment $(13,15)$.

In the most of the times the obstructive calculus is the only one and diameter varies from 2 to $5 \mathrm{~cm}(4,8,13,20)$.

Frequency of fistules alowing passage of calculus are in decreasing order in front of the cholecyst-duodenal, cholecyst-colonic, cholecyst-duodenocolonic and, by last, the choledocitis-duodenal. In the case of the colonic ones, they occur more frequently with the hepatic angle, being possible to occur with the transverse one and, exceptionally, directly with the sigmoid. $(10,12)$.

The premature relapse occurs when there are multiple vesicle calcules and the fistule is not adequately boarded. Multiple calcule are generally multifaced.

As migration of two or more calcules is possible, it is recommended, during the surgery, to inspect all the intestine segments $(1,3,5,12)$.

Literature discusses about extension of the surgical ileus-biliar treatment, comprising three options.

The first one consists in the enterolithotomy solving obstruction only.

The second is the two-phase surgery. In the first, enterolithotomy is done and, in the second, after 3 or 4 weeks, cholecystectomy and the cholecyst-enteric fistule resolution.

Third option is the one-phase surgery, enterolithotomy and cholecystectomy with correction of the cholecyst-enteric fistule.

Criteria that should direction treatment are the age of the patient, acid-basic and hydroeletrolitic balance conditions, associated diseases, residual cholelitiasis and presence of acute inflamatory process in the cholecystenteric fistule $(1,14,20)$. 


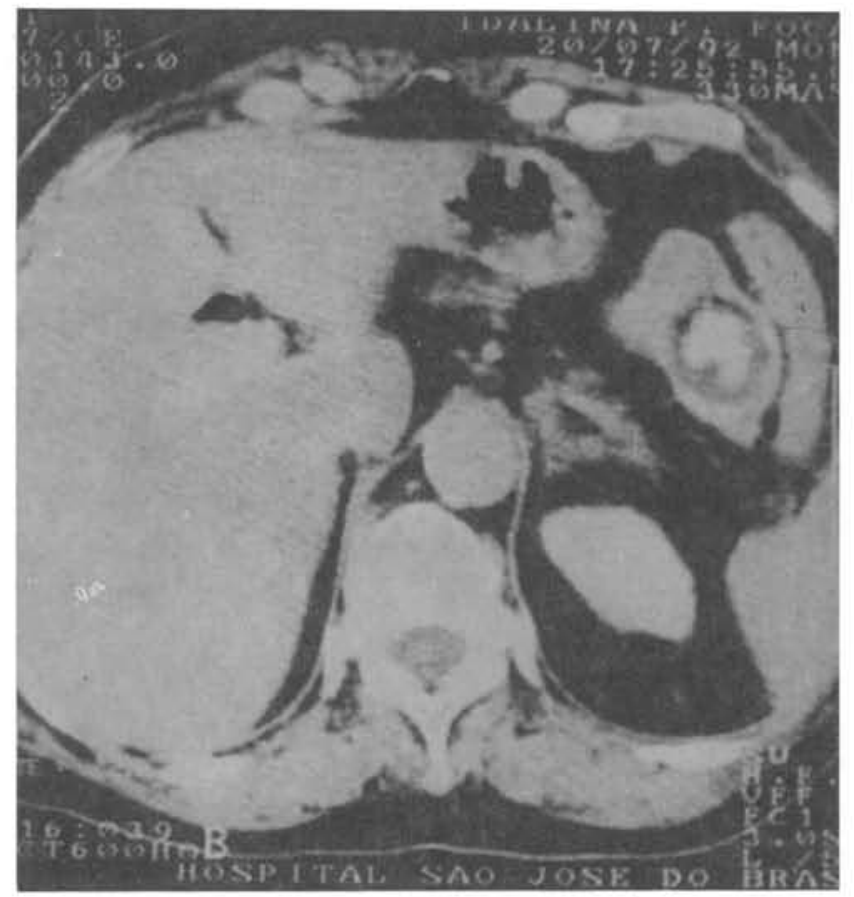

Figure 1 - Abdominal Computerized Tomography: Aerobilia and a $3,5 \mathrm{~cm}$ image of calcifications are observed, laminated periferically and crude in the center, corresponding to calculus impacted at the Treitz angle level

\section{Surgical techniques}

Enterolithotomy should be performed by a longitudinal incision, near to the obstruction at the contramesenteric edge, followed by transverse reapproximation. An enterectomy may be needed eventually, mainly if there is an intestinal perforation.

Manual propulsion to the ceco, so as a tripsis of the calculus may be done in selective cases, with the risk of resulting in injury of the enteric tissue $(4,9)$.

When there are multiple calcules, an incision next to the higher calculus enables the removal of the smaller ones.

In case of the obstruction of the sigmoid colon, the authors describe a proximal colotomy for the calculus removal, so as the extraction through a colonoscopy. However, preference is for the re-sectioning of sigmoid when stenosed, removing the segment attacked and the calcules $(13,15)$.

As in the present case a demonstration through the exames of the pre-operative image of the residual calcule absence was available, a two-phase surgery could have been chosen. However, as the clinical conditions alowed, the one-phase surgery was adopted, being the patient's satisfactory reaction a confirmation that right therapy has been decided upon.
It must be noted that, although the propulsion of calcule is condemned due to risk of injury to the rings tissue and distal obstruction of the sigmoid colon, in this case it was performed due to the spontaneous fragmentation of the calcule during the initial manipulation.

\section{Post-operative results}

The spontaneous closing of the cholecyst-enteric fistule may occur after the calculus migration, when there would not be residual calcules and the chystic duct enables passage $(11,16,17)$.

When cholecystectomy and bilio-digestive correction of fistule is not performed, some complications may occur,such as cholangitis, acute cholecystitis, intestinal obstruction relapse, choledocolitis, bleeding through fistule and biliar vesicle neoplasy.

Cholangitis occurs in $10 \%$ of cases with persistence of the cholecyst-enteria fistule and $60 \%$ of those with cholecyst-colonic fistule. Acute cholecystitis may occur through residual cholelitiasis and relapse of ileo-biliar is verified in $5 \%$ to $10 \%$ of the cases. Choledocolitiasis eventually installed may be cause of cholangitis as well. Bleeding may occur through the passage of the calculus through the fistule. Neoplasia of vesicle incides in $15 \%$ of patients with fistule persistence, versus the $0,8 \%$ of population in general $(5,7,11,16)$.

\section{CONCLUSION}

Definite correction of biliar ducto, although requiring more anesthesic/surgical time, does not increase mortality rates in comparison to the other types of treatment $(1,4,6,19,20)$.

One-phase surgery seems to be the indicated one, when the local and general conditions are favorable. Twophase treatment does not increase mortality, but implies in a longer confinement. Usually, implies in two different procedings in old aged patients.

When the biliar solution is not possible in the initial surgery, biliar disease symptoms or residual cholelitiasis justify a new selective surgery.

Patients that, after enterolithotomy without evident residual calcules, remain asymptomatic, may be followed by serial ultrasonography instead of a new surgical procedure. 
In high risk patients that, after enterolithotomy, present residual cholelithiasis, should be studied possibility of the use of litotripsia by waves of shock, chemical dissolution of the calcules, although the consequence of these procedings on the chronically inflamated areas are not yet wellknown, such as the found in the cholecystenteric fistules (4).

\section{RESUMO}

Objetivo: Os autores apresentam caso de íleo biliar como causa de obstrução mecânica alta, discutindo aspectos referentes ao diagnóstico e tratamento.

Discussão e Resultados: A obstrução intestinal mecânica causada pela passagem de cálculo da vesícula biliar para a luz intestinal através de fistulização, apesar de infreqüente, merece estudo pela morbi-mortalidade que apresenta.

A incidência em faixas etárias mais avançadas explica a associação com doenças crônico-degenerativas, aumentando a complexidade da decisão terapêutica.

A literatura discute a necessidade e a oportunidade da abordagem cirúrgica da fístula colecisto-entérica em um ou dois tempos diante da resolução da urgência obstrutiva e faz referência do íleo biliar sendo a causa de obstrução intestinal alta como exceção. A obstrução intestinal verificada com maior freqüência ocorre quando da impactação do cálculo biliar a nível da válvula íleo-cecal.

\section{REFERENCES}

1. ADORNI, A.; CAPOCASALE, E. \& LIVRINI, M. - Criteri per una scelta razionale di trattamento dell'íleo biliare. Minerva Chir 46:1033-7, 1991.

2. BRAVER, J.M. \& CLARKE, P.D. - Roentgenologic Clinical Pathologic Case. Invest Radiol 25:757-8, 1990.

3. BUETOW, G.W.; GLAUBITZ, J.P. \& CRAMPTON, R.S. Recurrent gallstone ileus. Surgery 54(5):716-24, 1963.

4. CLAVIEN, P.A.; RICHON, J.; BURGAN, S. \& ROHNER, A. - Gallstone ileus. Br J Surg 77:737-42, 1990.

5. COOPERMAN, A.M.; DICKSON, E.R. \& REMINE, W.H. - Changing Concepts in the Surgical Treatment of Galstone Ileus. Ann Surg 167(3):377-83, 1968.

6. DAY, E.A. \& MARKS, C. - Gallstone Ileus. Am J Surg 151:572-6, 1986.

7. DEITZ, D.M.; STANDAGE, B.A.; P.INSON, C.W.; MCCONNELL, D.B. \& KRIPPAEHNE, W.W. - Improving the Outcome in Gallstone Ileus. Am J Surg 129:552-8, 1975.

8. FOX, P.F - Planning the Operation for Cholecystoenteric Fistula with Gallstone Ileus. Surg Clin North Am 50(1):93$107,1970$.

9. KAPEL, O. - Operative Treatment of Gallstone Ileus Without Enterotomy. Acta Chir Scand 95:54-60, 1947.

10. KASAHARA, Y.; UMEMURA, H.; SHIRAHA, S.; KUYAMA, T.; SAKATA, K. \& KUBOTA, H. - Gallstone Ileus. Am J Surg 140:437-40, 1980.
11. PALOMAR DE LUIS, M.; TUBIA LANDABEREA, J.I. \& ELORZA ORUE, J.L. - Fístulas biliodigestivas espontáneas. Rev Esp Enf Digest 77(1):33-8, 1990.

12. PIEDAD, O.H. \& WELS, P.B. - Spontaneous Internal Biliary Fistula, Obstructive and Nonobstructive Types. Ann Surg 175(1):75-80, 1972.

13. PRYOR, J.H. - Gallstone Obstruction of the Sigmoid Colon with Particular Reference to Aetiology. Br J Surg 47:259. 61, 1959.

14. RÄF, L. \& SPANGEN, L. - Gallstone Ileus. Acta Chir Scand 137:665-75, 1971 .

15. SERRANO, R.; MONTANANA, A.; LACASA, J. Colelitiasis y fístula colecisto-colónica: una rara forma de íleo biliar. Rev Esp Enf Digest 77(1):55-7, 1990.

16. SVARTHOLM, E.; ANDRÉN-SANDBERG, A.; EVANDER, A.; JÄRHULT, J. \& THULIN, A. - Diagnosis and Treatment of Gallstone Ileus. Acta Chir Scand 148:4358, 1982.

17. SYME, R.G. - Management of Gallstone Ileus. Can J Surg 32:61-4, 1989.

18. VAN HILLO, M.; VAN DER VLIET, J.A.; WIGGERS, T.; OBERTOP, H.; TERPSTRA O.T. \& GREEP, J.M. - Gallstone obstruction of the intestine: An analysis of ten patients and a review of the literature. Surgery 101(3):273-6, 1987.

19. VAN LANDINGHAM, S.B. \& BRODERS, C.W. - Gallstone Ileus. Surg Clin North Am 62(2):241-7, 1982.

20. WARSHAW, A.L. \& BARTLETT, M.K. - Choice of Operation for Gallstone Intestinal Obstruction. Ann Surg 164(6): 1051-5, 1966. 